\title{
Exploring the Relationship among Export Resources, Exporting Capability \& Exporter-Foreign Distributers relationship on Export Performance: In the Case of Exporting Companies in Ethiopia
}

\author{
Getie Andualem Imiru ${ }^{1}$ \\ ${ }^{1}$ Associate Professor in Marketing Management, College of Business and Economics-School of Commerce, \\ Addis Ababa University, Ethiopia \\ Correspondence: Getie Andualem Imiru, Marketing Management, College of Business and Economics-School of \\ Commerce,_Addis Ababa University, Ethiopia.
}

Received: December 16, 2021

Accepted: February 21, 2022

Online Published: March 2, 2022

doi:10.5539/ijms.v14n1p60

URL: https://doi.org/10.5539/ijms.v14n1p60

\begin{abstract}
Export Performance and Economic Growth Relations are becoming the main agenda in the international and regional development programs around the world. The purpose of this study was to exploring the Relationship between Export Resources, Exporting Capability, Exporter-Foreign Distributers Relationship and their effect on Export Performance. Despite the fact that 300 questionnaires were issued to a random sample of Ethiopian exporters, 291 questionnaires were returned at the end of the data collection process, yielding a 97 percent response rate. Proportional stratified sampling approaches were used to sample small, medium, and large export businesses. The relationship between the exporter and the distributor, as well as the management of export resources, has a positive and significant impact on export performance. On the other side, export capabilities failed to mediate the relationship between export resources and export performance. The connection between Export Resources and Export Performance was mediated by Managing the Exporter-Distributor Relationship. Ethiopian exporters should focus on building strong ties with international distributors headquartered either at home or in the host countries to boost their export performance. Future research could look into the differences in the export business between larger, medium, and small exporters, all of whom have different resources, qualified personnel, bargaining strength, and so on. Finally, Resource capability's failure to mediate Export resources and export performance warrants further investigation. For undeveloped countries like Ethiopia, export is a critical component of economic growth and long-term development. As a result, policymakers should work to improve the country's export performance by increasing credit availability, simplifying export sector laws, and formulating short-term, medium-term, and long-term export growth plans. To enhance trade, the government should aid exporters in creating, nurturing, and growing stronger cooperation among national, regional, and worldwide distributors.
\end{abstract}

Keywords: export resources, export capability, foreign distributers, export performance

\section{Introduction}

The history of world economic development proves that countries in different continents were able to make themselves appear in the world economy after they took advantage of exploiting outward- looking economic opportunities. Most emerging countries implemented an import substitution program for economic growth in the 1950s and 1960s. In most developing countries, there has been a significant movement toward export promotion strategy since the mid-1970s. Export expansion, according to this concept, leads to better resource allocation, economies of scale, and production efficiency through technological advancements, capital formation, job creation, and hence economic growth. Export performance is generally determined by firms' production performance, but this analysis is more concerned with export performance after production. Traditionally, the determinants of exports as identified by many authors include economic size, distance, trade relations, common language, common border, colonial history, etc.

Export is an important ingredient for country's economic growth and sustainable development, like in Ethiopia; it is the back bone of the country's economy. Ethiopia has been concerned with diversifying its exports since the mid-twentieth century, when the late Emperor Haile Selassie devised the first five-year economic plan 
(1957-1961), which identified the ongoing dominance of two or three commodities (Lakew, 2003). Ethiopia's economy is a mixed and transitional economy with a significant public sector. Ethiopia's government is in the process of privatization numerous state-owned firms and transitioning to a market economy. Ethiopia has attempted to enhance export revenues by increasing the volume and variety of items exported. Since 1992, Ethiopian economic policy has emphasized export-led growth. Exports also provide much-needed foreign cash, which can be utilized to provide the public funding needed to shift manufacturing to the industries that will boost growth the greatest. The role of export-led growth (ELG) on overall economic performance has been extensively discussed in the literature. Exports help to enhance the balance of payments, employment rate, and living standards; as a result, a growing number of governments are attempting to assist and encourage their exporters to increase their exports (Doaei \& Hassani, 2010).

It has also developed several plans and implemented various policy reforms. According to Lakew (2003), exports were unable to fill the fiscal deficits created by imports, resulting in a reduced exports-to-GDP ratio and deteriorating terms of trade. Gold (21 percent of total exports) and coffee are Ethiopia's principal exports (19 percent). Live animals, oilseeds, flowers, and khat are among the others. Switzerland is Ethiopia's major export partner (21 percent of total exports), primarily for gold shipments. The dominance of agricultural commodities in general and coffee in particular, has not shifted significantly, and export concentration of a few commodities remains an issue. Ethiopia is a developing East African country going through political, economic, social and technological transitions. The country's development strategy has the objectives of promoting rapid economic growth with a stable economic atmosphere and enhancing the integration of country's economy with a global economy (Allaro, 2012). Ethiopia's potential for export of manufactured goods lies in textile, leather and leather products, as well as products of agro-processing. Exporters have a good possibility of increasing export due to the availability of all-important elements in the country at a reasonable price.

Using trade to drive faster growth is essential to Ethiopia's aspirations to join the ranks of middle-income states by the year 2025. Over the past 15 years, the value of Ethiopian exports increased by $549 \%$. Nevertheless, even faster import growth has led to a worsening balance of payments deficit, making the country's competitiveness in international markets an urgent priority. Several study papers (both international and local studies) have looked into what export managers from a variety of countries and firm sizes think about a variety of factors that could affect export performance. To this researcher's knowledge, there is no current study in the international business literature that studies Export managers' viewpoints on the factors of export success in relation to Export resources and capabilities, Exporter-foreign distributer relationships, and export performance in Ethiopia.

Export performance and economic growth relations are becoming the main agenda in the international and regional development programs around the world (International Labour Office, 2015). In the case of Ethiopian exporting enterprises, researching the relationship between export resources, exporting capability, and overseas distributers, as well as their links to export performance, is crucial. As a result, the following research questions were addressed in this study.

- Is there a link between export resources, export capability, and the control of the connection between exporters and overseas distributers, as well as export performance?

- What impact does export capacity have on export performance?

- Is there a link between export capabilities and export performance?

- To what extent does the relationship between the exporter and the foreign distributer mediate export resource, export resource, and export performance?

This study covers the following topics: literature review, research model, hypothesis generation, methods, results, discussion, conclusion, limitation, and future research directions.

\section{Literature Review}

The state of knowledge in the field of international trade and business has progressed. In the export business, there is sufficient theoretical and empirical evidence. Researchers have utilized a range of basic theories to explain company internationalization. TCA (Anderson, 1986; Lee, Koh, \& Heo, 2011), RBV (Mariz-Pérez \& Garcá-lvarez, 2009; Sharma, 1999; Westhead \& Wright, 2001), and network theory (Elo, 2005; Fletcher, 2008) are only a few examples (Schwens \& Kabst, 2009).

\subsection{The Resource-Based View (RBV)}

The resource-based view (RBV) literature has mostly assumed that a company's export performance is determined by a proper combination of its own resources and capabilities (Kaleka, 2002). As a result of increased globalization 
and the economic crisis, many small and medium-sized businesses (SMEs) have been pushed to internationalize their products or services, with exporting being the more extensive entry route (Stoian, 2011).

\section{Critiques of the Resource Based View (RBV)}

The resource-based view (RBV) has become one of the most influential and referenced viewpoints in management philosophy. RBV's purpose is to illustrate how a company's long-term competitive advantage comes from within (SCA). Several studies, including core competencies (Hamel \& Prahalad, 1994), dynamic capacities (Helfat \& Peteraf, 2003; Teece, Pisano, \& Shuen, 1997), and the knowledge-based view (KBV), all back up this claim (Grant, 1996b). On the other side, RBV has been chastised for a slew of faults.

- The RBV, according to one criticism, lacks "operational validity" and significant managerial implications (Priem \& Butler, 2001a). It claims to advise managers on how to build and collect VRIN resources, as well as how to form an acceptable structure, although it is unclear how to accomplish so (Connor, 2002; Miller, 2003).

- The RBV's generalizability argument. "A company that excels at putting mechanisms in place to improve product innovation will eventually outperform the company with the best product innovation capabilities today..." Collis is a fictitious character from the movie Collis (1994, p. 148). According to the RBV, organizations should pursue second-order capabilities (building structures that facilitate product innovation) since they will eventually be more valuable than first-order capabilities (product innovation). According to this hypothesis, this phase can be repeated indefinitely, culminating in a never-ending search for higher-order talents.

- According to Gibbert, resource uniqueness (the blending of heterogeneity and immobility) prevents the RBV from having any ex ante generalization potential (2006a, 2006b). When it comes to uniqueness, it's impossible to generalize. The RBV, according to Connor (2002), only applies to large enterprises with significant market power. According to him, the SCA of smaller and more agile businesses cannot be based on static resources, and thus they fall outside the RBV's jurisdiction. The resources a corporation needs to produce SCA, according to Miller's (2003) discussion paper on "sustainable attainability," are those that are difficult to gain in the first place. Miller's argument is that additional VRIN resources can only be bought and used by organizations that currently have them

- The purpose of the RBV is to construct a SCA that will survive attempts to copy or remove it. Fiol (2001) clearly refutes this assumption, arguing that "both skills/resources and how companies exploit them must constantly adapt, resulting in the emergence of constantly shifting transitory advantages" (Fiol, 2001, p. 692).

- Conner (1991) and Kogut and Zander (1993) proposed that the RBV may be considered a new firm theory (1992). They concluded that the RBV is striving to be a firm theory, one that differs materially from other firm theories available, particularly transaction cost economics (TCE) (Williamson \& Winter, 1991). The RBV is insufficient as a firm theory, according to Foss (1996a, 1996b). The RBV emphasizes the differences between businesses and people, as well as why enterprises are better at earning rent than people.

- When resources and capabilities are valuable, rare, inimitable, and non-substitutable (VRIN), as well as when a sufficient organization is in place (O), SCA can be realized (Barney, 1994). The VRIN/O criteria are neither adequate nor required to explain SCA, and the RBV has minimal empirical support (Armstrong \& Shimizu, 2007; Newbert, 2007).

These arguments imply fundamental disputes regarding the nature of markets, persons, and resources, as well as their roles in the generation of SCA. Despite the above criticisms, the RBV has been widely adopted as a central theory of SCA in the literature, in fact, through re-consideration of Critiques.

\subsection{Network-Based Theories}

Ripollés et al. (2012) define networking capability as a company's ability to develop and leverage inter-organizational relationships in order to gain access to specific resources controlled by other stakeholders. Networking capability is defined by Farooqi, Miog and Bengtsson (2012) as a company's ability to gather resources from the environment through partnerships and social relationships for use in international trade. As a result, networking ability is viewed as a dynamic talent, as it allows a company to recognize opportunities and respond fast (Knight \& Liesch, 2016). The ability to network is a key factor in the success of a small business (Parida \& Rtqvist, 2015). Controlling the internal and external flow of information, in particular, will have an impact on enterprising SMEs' productivity by encouraging knowledge exchange and cost reduction. 
Given the importance of overcoming the "resource shortage" required to compete in the international environment (Karami \& Tang, 2019; Ripollés, Blesa, \& Monferrer, 2012), networking capability has been a popular topic in internationalization research in recent years, with a particular focus on SMEs (Karami \& Tang, 2019; Ripollés, Blesa, \& Monferrer, 2012). Networking interactions help internationalization by reducing the cost and time of process integration (Musteen, Francis, \& Datta, 2010), enhancing internationalization performance (Lin \& Chaney, 2007), and lowering the cost and time of process integration (Musteen, Francis, \& Datta, 2010; Musteen, Francis, \& Datta, 2010; Redding, 1996).

\subsection{Transaction Cost Theory (TCT)}

According to transaction cost theory (Williamson, 1979, 1986), the ideal organizational structure is one that maximizes economic efficiency while minimizes exchange costs. According to the theory, there is coordination costs associated with monitoring, controlling, and managing transactions for each type of transaction. Export intermediary firms assist inexperienced exporters as well as experienced exporters (including multinational corporations) in breaking into new markets (Peng \& York, 2001). They are "specialist enterprises that operate as export departments for a number of non-competitive industries," according to the definition (Root, 1994, p. 102). According to Peng and York (2001), Kumar and Bergstrom (2007), and Shahrul (2011), these businesses are critical in assisting exporters in reaching a bigger international market.

Costs are expected to be high when interacting across borders; so, export intermediates may be used "to lower the cost of creating exports sales" (Beamish, Karavis, Goerzen, \& Lane, 1999, p. 39 cited in Peng \& York, 2001). To understand how the transaction cost theory works in an international environment, it's important to understand that when it comes to exporting, producers have two options: they can either export directly or indirectly through intermediaries. Export intermediates must be able to convince exporters to pick the second option by lowering their clients' export-related transaction costs compared to direct exporting. The success of these intermediaries in lowering such expenses determines their performance.

Transaction cost theory has been criticized for its limited applicability and for focusing too much on structural aspects of trading at the detriment of other important factors. According to Zajac and Olsen (1993), when trying to restrict opportunistic behavior, management has been forced to focus on predicted gains rather than anticipated losses. This strategy is also criticized as a mistake when making explicit or implicit assumptions that firms in a given industry are homogeneous. In the real world, "firm homogeneity is incorrectly assumed" (Robson, Leonidou, \& Katsikeas, 2002, p. 389) because no two businesses have the same resources and technologies (Kogut, 1988; Dyer, 1997). Finally, resource-based theory, network-based theory, and transaction theory are synthesized or integrated in this study to examine the system's performance.

Transaction cost theory has been criticized for its limited applicability and for focusing too much on structural characteristics of trading at the expense of other crucial considerations. This constraint, according to Zajac and Olsen (1993), has pushed management to focus on projected gains rather than anticipated losses when seeking to control opportunistic behavior. When making explicit or tacit assumptions that enterprises in a certain industry are homogeneous, this method is also criticized as a mistake. "Firm homogeneity is unrealistically assumed" (Robson, Leonidou, \& Katsikeas, 2002, p. 389) in the real world because no two businesses have the same resources and technologies (Kogut, 1988; Dyer, 1997). Finally, resource-based theory, network-based theory, and transaction theory are synthesized or integrated in this study to evaluate the performance of the Ethiopian export sector. The TCT can strongly explain cost concerns that surround decisions to be engaged in local or export businesses. Businesses need to be assured of the advantage of being engaged in export trade before spending their resources to initiation and conducting export activities.

\section{The Study's Variables}

In many research reviews, many variables were discovered to be used to explain export performance. For example, the resource-based approach asserts that valuable, rare, socially complex, and unique resources and capabilities enable businesses to establish marketplace advantages (Barney, 1991), highlighting the heterogeneity of capabilities firms use to achieve superior performance (Barney, 1991; Wernerfelt, 1984). Export Resources, Export Capacity, Managing Foreign Distributers, and Export Performance and Sub-Constructs Are All Factors That Are Considered in This Study:

\subsection{Export Resource}

Knowledge stocks, physical assets, human capital, and other tangible and intangible things owned or controlled are all examples of resources (Teece, Pisano, \& Shuen, 1997). Exporting enterprises are made up of a variety of assets and skilled employees. Rather than the simple aggregation of all of these characteristics, it is the synergistic effects 
caused by their combinations that matter most in the process of developing competitive advantage (Barney, 1991; Amit \& Schoemaker, 1993). Organizational resources are regarded the ultimate sources of competitive advantage since enterprises are distinctive in terms of the bundle of resources that they gather over time. Physical assets, size of operation, financial assets, and the firm's experience in export market operations are identified as four categories of competitive resources for exporters by Kaleka (2011). In an inter-organizational context, Kaleka (2012) discovers that the majority of these critical resources have a favorable impact on various outcomes.

\subsection{Export Capability}

Marketing studies look at how to gain a competitive advantage by optimizing skills and keeping resources current (Kaleka, 2011). When it comes to international performance, Lu et al. (2010) find that the firm's ability to coordinate, recombine, and allocate resources to meet multiple needs mediates the relationship between resources and performance. It's critical to distinguish between operational and dynamic capabilities in the context of internationalization (Weerawardena, 2019): Dynamic capabilities "build, integrate, or reconfigure operational capabilities" (Helfat \& Peteraf, 2003). Operational capabilities "generally involves performing an activity using a collection of routines executing to execute and coordinate the variety of tasks required to perform the activity" (Helfat \& Peteraf, 2003, p. 999). Dynamic capabilities emphasize the integration, construction, reconfiguration, and renewal of capabilities to cope with changing environments, focusing on the company's ability to exploit and reconfigure resources to generate new forms of sustainable competitive advantage. According to Kaleka (2002), the four major skills in export markets are information, customer connection building, product creation, and supply chain management. Based on a meta-analysis, Weerawardena et al. (2019) believe that marketing capabilities can lead to export performance; however, Kaleka (2002) asserts that informational capabilities have a direct positive impact on export performance.

\subsection{Exporter-Distributor Relationship Management}

The search for the selection of distributors is a key procedure that, if done improperly, can have major consequences. A bad distributor can bankrupt a firm or producer and put them at a competitive disadvantage (Hill \& Blois, 1989). Due to the time and profit costs associated with having an ineffective foreign distributor in an export market, it may be preferable to have no distributor at all (Cavusgil, Yeoh, \& Mitri, 1995). Use a relational approach to intermediary decision-making rather to opting for an option that meets criteria like convenience or availability (Lewin \& Johnston, 1997).

The task of selecting a foreign distributer has been suggested by Root (1994). The four stages of the screening process are creating the distributor profile, locating distributer prospects, assessing distributer prospects, evaluating distributer prospects, and selecting the distributer. Having a close relationship with and supporting distributor's leads to greater performance and happiness for both parties (Bello \& colleagues, 2003). Because the producer or exporter does not have a permanent market presence on their behalf, the options available to them are limited (Shipley et al., 1995). whatever the obstacles, effective distributer control must be adopted (ibid). This will require the creation of a set of criteria as well as the monitoring of relevant actions. Managerial preferences, information availability, and the specific performance to be measured all impact control and assessment measures (Haas, 1995). Kang et al. (2018) discovered control mechanisms to be one of the most effective inter-organizational drivers of marketing channel effectiveness across several theoretical approaches. According to $\mathrm{RBV}$, information and communication technologies do not create a competitive advantage because they are not unique (Barney, Wright, \& Ketchen, 2001).

- Outcome-Based (Output) Control refers to formal instruments used to track and evaluate the degree to which intermediaries' results or outcomes are met. Managers of exporters signal their key objectives to intermediaries and make clear the monitoring of intermediaries' outcomes; managers transfer the risk of goal achievement to intermediaries (Aulakh \& Gencturk, 2000), holding them accountable regardless of the means they use to achieve the outcomes (Mellewigt, Ehrmann, \& Decker, 2011; Su, Baird, \& Schoch, 2013), and reducing interest (Bello \& Gilliland, 1997).

- Behavior-Based (Process) Control refers to the level to which the exporter watches the conduct of intermediaries or the mechanisms by which desired outputs are achieved, and ensures that desirable actions are taken while avoiding bad ones. The purpose of process devices is to persuade intermediaries to concentrate their resources and managerial attention on selling and servicing exporter's products (Bello \& Gilliland, 1997).

- Social Control/Informal (social or norm-based) controls are unwritten systems that influence behavior by leveraging "values, conventions, and cultures to support desirable behavior" (Das \& Teng, 2004). Professional and cultural controls are examples of informal controls (Jaworski, 1988; Ouchi, 1979, p. 82). 
Professional control refers to (inter)organizational members internalizing behavioral norms based on prevailing social perspectives and patterns of interpersonal interactions (Jaworski, 1988; Guenzi, Baldauf, \& Panagopoulos, 2014) outside the hierarchical command system, such as training, seminars, working collaboration, and spontaneous interactions over time (Kang, Asare, \& Brashear-Ale, 2010). Norms, rituals, and values that guide people's behavior are referred to as cultural control.

\subsection{Export Performance}

Export performance refers to the outcome of a company's actions in export markets (Shoham, 1998). However, there is no one-size-fits-all metric of export performance that takes into account the multifaceted nature of performance (Cavusgil, Zou, Leonidou, Katsikeas, Samiee, Taylor, \& Osland, 1998). Export performance can be defined as "export effectiveness," "export efficiency," and "continuous participation in exporting" (Shoham, 1991). Export performance is measured using a range of metrics, the most frequent of which are export intensity, export sales growth, export profit level, export sales volume, export market share, and export profit contribution (Dhanaraj \& Beamish, 2003; Katsikeas, Leonidou, \& Morgan, 2000, 2003).

Export performance can be measured objectively or subjectively (Chen et al., 2016; Lu, Quester, Medlin, \& Scholz, 2012). Subjective metrics are commonly perceived values (e.g., the manager's appraisal of export sales performance and happiness), whereas objective metrics are typically absolute measures (e.g., export profit margin, export market share, export sales volume) (Chen et al., 2016; Morgan, Katsikeas, \& Vorhies, 2012). According to international business experts, objective and subjective measures complement each other and should be considered synonymous to present a truer picture of export performance (Bloemer et al., 2013; Boso et al., 2013; Madsen \& Moen, 2018).

\subsection{Control Variables}

Control variables are factors or aspects that researchers try to keep constant throughout their studies in order to avoid influencing the results. The influence of an independent variable on a dependent variable is measured in a typical study design. For the sake of validity, two control variables were used in this study. First, the firm's Export Importance as a proxy for Export Intensity, which measures internationalization; this index is determined by the ratio of export sales to total sales revenue, as used in most international studies (Westhead, Wright, \& Ucbasaran, 2001; Acedo \& Casillas, 2007; Hsu \& Wang, 2012). Second, the Importance of the Export Relationship, as evaluated by the percentage of sales generated through the foreign intermediary; this variable shows both total exposure to potential opportunism and the requirement for coordination with the intermediary (Dekker, Sakaguchi, \& Kawai, 2013).

\section{Conceptual Framework and Hypothesis of the Study}

The study's conceptual framework includes four categories of variables that will be examined. These categories are: Export Resources, Export Capabilities, exporter-foreign intermediaries' relationships and export Performance is shown the Figure 1. 


\subsection{Conceptual Framework of the Study}

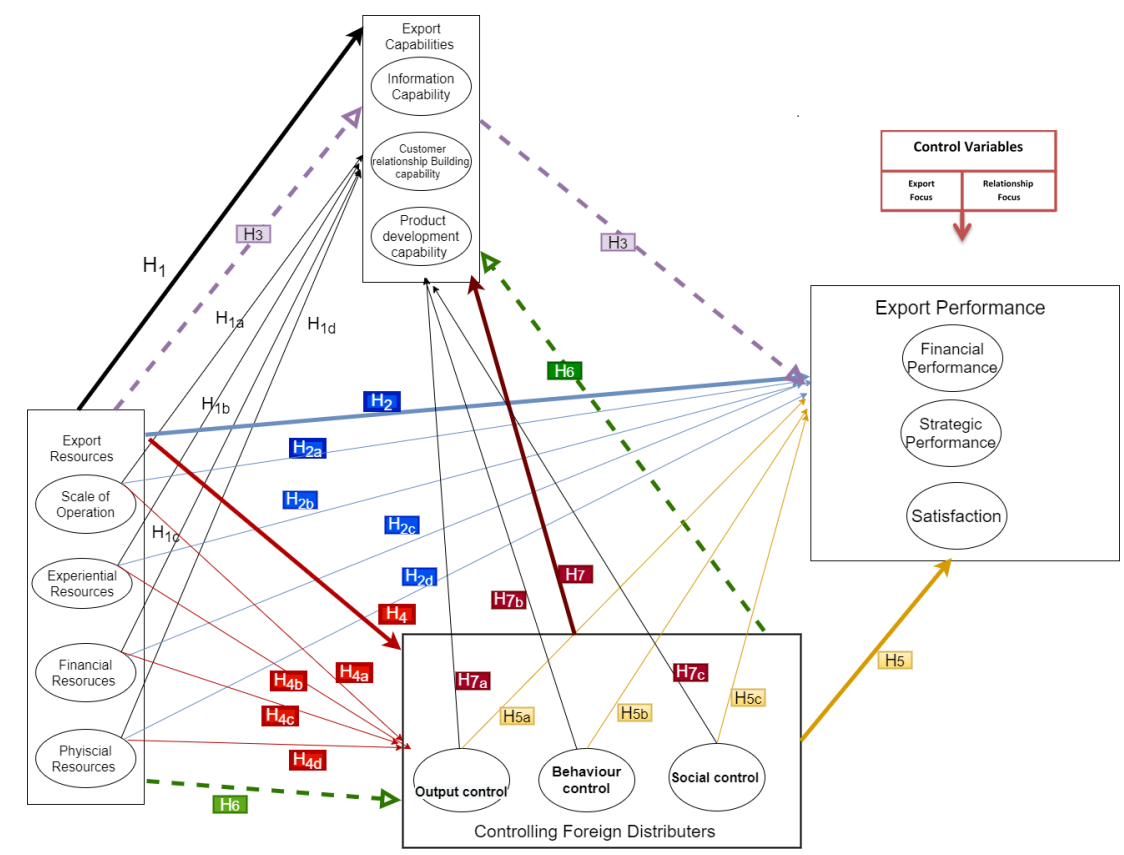

Figure 1. Exploring the relationship between export resources, export capabilities \& controlling and managing foreign distributers with export performance model with hypothesis

\subsection{Hypothesis of the Study}

The Composite hypotheses of this research are seven, which are set using the research questions specified above and were tested as given below:

H1: There is a significant and positive relationship between Export Resources and Export Capabilities. There are four sub-hypotheses for $\mathbf{H 1}$;

H1a: Scale of Operation has a significant \& positive effect on Export Capabilities

H1b: Experiential Relation has a significant \& positive effect on Export Capabilities

H1c: Financial Resource has a significant \& positive effect on Export Capabilities

H1d: Physical Resource has a significant \& positive on Export Capabilities

H-2: There is a significant and positive relationship between Export Resources and Export Performance.

There are four sub-hypotheses for $\mathrm{H} 2$ :

H2a: Scale of Operation has a significant \& positive effect on Export Performance

H2b: Experiential Relation has a significant \& positive effect on Export Performance

H2c: Financial Resource has a significant \& positive effect on Export Performance

H2d: Physical Resource has a significant \& positive on Export Performance

H-3: Export Capabilities Mediate the Relationship between Export Resources and Export Performance.

H-4: There is a significant and positive relationship between Export Resources and Exporter Distributor Relationship Management (EDRMs).

There are four sub-hypotheses for $\mathbf{H} \mathbf{4}$ :

H4a: Scale of Operation has a significant \& positive effect on EDRMs.

H4b: Experiential Relation has a significant \& positive effect on EDRMs.

H4c: Financial Resource has a significant \& positive effect on EDRMs. 
H4d: Physical Resource has a significant \& positive on EDRMs.

\section{H-5: There is a significant and positive relationship between EDRMs and Export Performance.}

There are three sub-hypotheses for H5:

H5a: Output control has a significant \& positive effect on Export Performance.

H5b: Behaviour control has a significant \& positive effect on Export Performance.

H5c: Social control has a significant \& positive effect on Export Performance.

\section{H-6: Export-distributer relationship mediates the relationship between Export Resources and Export Capabilities.}

H-7: There is a Significant and Positive Relationship between Exporter-distributer relationship and Export Capabilities.

There are three sub-hypotheses for H5:

H7a: Output control has a significant \& positive effect on Export Capabilities.

H7b: Behaviour control has a significant \& positive effect on Export Capabilities.

H7c: Social control has a significant \& positive effect on Export Capabilities.

\section{Methodology}

Initially, the literature was reviewed through to uncover indicators that influence export performance. Export resources, export capabilities, and managing foreign distributers were all recognized as a result. On the basis of these data, a research questionnaire was created, as well as hypotheses. The dependability of the research questionnaire was assessed. The information was then gathered by sending a structured online questionnaire to Ethiopian exporters of a variety of items. The obtained data was then examined, and conclusions and recommendations based on the findings were made.The Ethiopian Chamber of Commerce and sectoral organizations presented a list of exporters as the sampling frame. The companies were picked at random from a pool of 300 exporting companies that matched four criteria: They were autonomous entities with a strong international emphasis, earned a large amount of money from export activities, had at least five years of experience in the export industry, and had contact information for senior managers and experts, among other things.

\section{Results of the Study}

\subsection{Demographic Profile}

Despite the fact that 300 questionnaires were distributed to a sample of exporters from a total of 920 exporters in the country, only 291 questionnaires were returned at the end of the data collection procedure, resulting in a 97 percent response rate. Table 1 shows the demographic characteristics of the respondents. In terms of product export, the bulk of respondents (87\%) were agricultural product exporters, followed by (13\%), manufacture, and 3\% service exporters. In terms of years in the export business, 44 percent had been in it for 1 to 5 years, 36 percent had been in it for 6 to 10 years, 15 percent had been in it for 11 to 20 years, and $5 \%$ had been in it for more than 20 years. In terms of the number of markets in which an exporting company operates, the majority of respondents $(51 \%)$ operate in 1-3 countries, $37 \%$ operate in 4-6 countries, $8 \%$ operate in $6-20$ countries, and 4\% operate in more than 10 countries.

Table 1. Profile of respondents

\begin{tabular}{llll}
\hline Item & Description & Frequency & $\%$ \\
\hline Type of Product export & Agricultural products & $87 \%$ & $13 \%$ \\
& Manufactured products & 30 & $3 \%$ \\
& Services & 9 & $100 \%$ \\
Number of years in the export & Total & 291 & $44 \%$ \\
business & $1-5$ years & 128 & $36 \%$ \\
& $6-10$ years & 105 & $15 \%$ \\
Number of markets the exporting & $11-20$ years & 44 & $5 \%$ \\
Company is operating & above 2o years & 15 & $100 \%$ \\
& Total & 291 & $51 \%$ \\
& $4-6$ countries & 147 & $37 \%$ \\
& $6-10$ countries & 110 & $8 \%$ \\
& More than 10 countries & 22 & $4 \%$ \\
\end{tabular}




\subsection{Data Analysis and Hypothesis Examination}

Using the SmartPLS 3 software, the Partial Least Squares (PLS) technique was used to assess the study model (Ringle, Wende, \& Becker, 2018). SmartPLS is a popular Partial Least Squares Structural Equation Modelling software tool (PLS-SEM). Hair et al. (2017), Ramayah et al. (2011, 2013) and Rahman et al. (2016) employed a two-stage analytical procedure to analyse data validity and reliability, followed by a structural model analysis (testing the hypothesized link) using Anderson and Gerbing's method (1988). A bootstrapping method (5000 resamples) was used to test the significance of the path coefficients and loadings (Hair et al., 2017).

\subsection{Measurement Model}

Before employing the SMART-PLS statistical tool to analyze the data, it was first entered into SPSS and a preliminary stage of measurement item was determined. The psychometric features of the assessment model were then evaluated using SMART-PLS in terms of internal consistency, reliability, convergent validity, and discriminant validity. The Measure of Sampling Adequacy (0.893) and overall Cronbach alpha (0.897) reliability measures were also confirmed using SPSS 22. As a data reduction technique, SMART PLS uses factor analysis. As a result, 43 different objects were used in this study. Two types of validity were studied to evaluate the measurement model: convergent validity and discriminant validity.

\subsection{Reliability and Convergent Validity}

To determine the measurement's convergent validity, the loadings, average variance extracted (AVE), and composite reliability are typically used (Gholami et al., 2013; Rahman et al., 2015). The loadings were all greater than 0.7, the composite reliabilities were all greater than 0.70, and the AVE of all constructs were all greater than 0.5, as predicted by the literature (See Tables 2, 3, and 4 for more information). A measurement instrument is said to be trustworthy when the question-statements (or other measures) associated with each latent variable are understood in the same way by different respondents. As a result, all Cronbach alpha coefficients assessing a set of scale items' unidimensionality are greater than 0.70 , ranging from 0.830 to 0.882 , showing strong internal consistency.

On the other hand, Cronbach alpha is based on the limiting assumption that all indicators are equally important. Another approach to think about dependability is as the fraction of measure variance that can be explained by the underlying dimension (Werts et al., 1974). According to Chin et al. (1996, p. 33), whereas Cronbach's alpha with its assumption of parallel measures gives a lower bound estimate of internal consistency, the composite reliability yields a superior approximation. Similarly, the composite reliability of all latent variables is above 0.7 for all measures, ranging from 0.877 to 0.907 . Similarly, the Dhillon Goldstin rho, which must be greater than 0.7 , evaluates internal consistency in the same way as composite reliability does (Gefen, 2000). On the other hand, the average variance extraction (AVE) of all variables is more than 0.5. Typically, the AVE criterion for sufficient validity is set at 0.5 (Fornell \& Larcker, 1981).

Table 2. Reliability analysis

\begin{tabular}{lllll}
\hline Construct Reliability and Validity & Cronbach's Alpha & rho_A & Composite Reliability & Average Variance Extracted (AVE) \\
\hline EDRM & 0.847 & 0.854 & 0.877 & 0.558 \\
EC & 0.864 & 0.873 & 0.895 & 0.695 \\
EP & 0.882 & 0.893 & 0.907 & 0.552 \\
ER & 0.830 & 0.835 & 0.868 & 0.599 \\
EXR & 0.864 & 0.860 & 0.887 & 0.566 \\
FIR & 0.882 & 0.894 & 0.907 & 0.697 \\
PHR & 0.720 & 0.723 & 0.844 & 0.644 \\
SOR & 0.706 & 0.722 & 0.834 & 0.715 \\
BBC & 0.745 & 0.716 & 0.781 & 0.578 \\
MRWD & 0.757 & 0.808 & 0.712 & 0.580 \\
SOCO & 0.822 & 0.877 & 0.641 \\
CV & 0.813 & 0.603 & 0.795 & 0.660 \\
\hline
\end{tabular}

\subsection{Construct Validity}

The construct validity of a set of measures determines if they are true constructs that describe an event (Straub, 1989).There are two types of procedures for determining the construct validity of an instrument: When AVE is more than 0.5 , convergent validity refers to the degree to which multiple attempts to gauge the same concept agree. 
Discriminant validity refers to the degree to which the measures of different notions are distinct.

\subsection{Discriminant Validity}

Discriminant validity is a method of guaranteeing that one concept stands out from the rest. The Fornell-Larcker criterion can also be used to determine discriminant validity using AVE: each latent variable's square root should be greater than its correlation with every other latent variable. This means that each latent variable's variance with its block of indicators is bigger than any latent variable's variance with any other latent variable. In SmartPLS output, the square root of AVE appears in the diagonal cells of the Fornell-Larcker criterion table, and correlations appear below it. In absolute value words, discriminant validity exists if the top number (which is the square root of AVE) in any factor column is greater than the numbers (correlations) below it.

One may conclude that discriminant validity is not an issue when the square root of AVE or correlation is positioned on the table's diagonal, as shown in Table 3, and it is higher than the other values in the column. In this study, the AVE of the latent variable 'EDRM' is 0.558 ; hence its square root is 0.747 . This figure is higher than the correlation values in the EDRM column. The results indicate that discriminant validity has been established.

Table 3. Latent variable correlation and discriminant validity

\begin{tabular}{|c|c|c|c|c|c|c|c|c|c|c|c|}
\hline & EDRM & EC & EP & ER & EXR & FIR & PHR & SOR & $\mathrm{BBC}$ & SOR & SOCO \\
\hline EDRM & 0.747 & & & & & & & & & & \\
\hline EC & 0.455 & 0.834 & & & & & & & & & \\
\hline EP & 0.510 & 0.487 & 0.743 & & & & & & & & \\
\hline ER & 0.366 & 0.373 & 0.570 & 0.748 & & & & & & & \\
\hline EXR & 0.376 & 0.285 & 0.440 & 0.285 & 0.752 & & & & & & \\
\hline FIR & 0.596 & 0.431 & 0.339 & 0.531 & 0.317 & 0.835 & & & & & \\
\hline PHR & 0.541 & 0.344 & 0.473 & 0.304 & 0.575 & 0.497 & 0.802 & & & & \\
\hline SOR & 0.505 & 0.398 & 0.503 & 0.168 & 0.496 & 0.312 & 0.538 & 0.846 & & & \\
\hline $\mathrm{BBC}$ & 0.334 & 0.476 & 0.678 & 0.576 & 0.327 & 0.334 & 0.446 & 0.428 & 0.760 & & \\
\hline SOR & 0.241 & 0.761 & 0.399 & 0.162 & 0.190 & 0.258 & 0.262 & 0.319 & 0.464 & 0.762 & \\
\hline SOCO & 0.248 & 0.558 & 0.614 & 0.453 & 0.164 & 0.272 & 0.355 & 0.373 & 0.646 & 0.523 & 0.801 \\
\hline
\end{tabular}

\subsection{Factor Loading, P-Values and T-Statistics}

Factor structure should be simple in an ideal world, which means projected loadings should be greater than 0.7 (Some people use .4). All of the indicators in the table above loaded properly on their respective factors. In a good model, indicators should load well on the items they're designed to measure, and cross-loadings with aspects they're not supposed to measure should be obvious. When each measuring item correlates weakly with all other constructs save the one with which it is theoretically connected, discriminant validity is proven. When the correlation of the latent variable score with the measurement item must indicate an adequate pattern of loading, in which the measurement item loads heavily on their theoretically assigned component but not heavily on others. All of the loadings in this scenario revealed a more appropriate pattern loading than the cross loading of the other variables. At the very least, no indicator variable should have a greater correlation than the others.

When the correlation between the latent variable score and the measurement item must show a sufficient pattern of loading, in which the measurement item loads significantly on their theoretically assigned component but not on others. In this instance, all of the loadings revealed that the pattern loading was more appropriate than the cross loading of the other variables. At the very least, no indicator variable should have a larger correlation with another latent variable than it does with its own latent variable. If it does, the model has been provided incorrectly. 
Table 4. Descriptive and factor loading

\begin{tabular}{|c|c|c|c|c|c|}
\hline & Factor Loading & Mean $(\mathrm{M})$ & (STDEV) & T Statistics (|FL/STDEV|) & P-Values \\
\hline $\mathrm{BBC} 1<-\mathrm{EDRM}$ & $0.787 * * *$ & 0.498 & 0.052 & 15.063 & 0.000 \\
\hline $\mathrm{BBC} 2<-\mathrm{EDRM}$ & $0.722 * * *$ & 0.586 & 0.049 & 14.708 & 0.000 \\
\hline $\mathrm{BBC} 3<-\mathrm{EDRM}$ & $0.783 * * *$ & 0.679 & 0.035 & 22.415 & 0.000 \\
\hline $\mathrm{BBC} 4<-\mathrm{EDRM}$ & $0.736 * * *$ & 0.630 & 0.038 & 19.140 & 0.000 \\
\hline MRWD1 <- EDRM & $0.718 * * *$ & 0.582 & 0.049 & 14.600 & 0.000 \\
\hline MRWD2 <- EDRM & $0.703 * * *$ & 0.568 & 0.041 & 16.990 & 0.000 \\
\hline MRWD3 <- EDRM & $0.711 * * *$ & 0.422 & 0.066 & 10.723 & 0.000 \\
\hline MRWD4 <- EDRM & $0.764 * * *$ & 0.476 & 0.058 & 13.131 & 0.000 \\
\hline MRWD5 <- EDRM & $0.775 * * *$ & 0.489 & 0.049 & 15.711 & 0.000 \\
\hline SOCO1 <- EDRM & $0.802 * * *$ & 0.695 & 0.039 & 20.460 & 0.000 \\
\hline $\mathrm{SOCO} 2<-$ EDRM & $0.704 * * *$ & 0.703 & 0.031 & 22.401 & 0.000 \\
\hline $\mathrm{SOCO} 3<-$ EDRM & $0.795 * * *$ & 0.690 & 0.031 & 26.038 & 0.000 \\
\hline SOCO4 <- EDRM & $0.750 * * *$ & 0.645 & 0.043 & 17.242 & 0.000 \\
\hline CRBC1 <- Export Capabilities & $0.750 * * *$ & 0.753 & 0.032 & 23.643 & 0.000 \\
\hline CRBC2 <- Export Capabilities & $0.773 * * *$ & 0.772 & 0.028 & 27.664 & 0.000 \\
\hline INC1 <- Export Capabilities & $0.701 * * *$ & 0.554 & 0.051 & 13.659 & 0.000 \\
\hline INC2 <- Export Capabilities & $0.726 * * *$ & 0.481 & 0.059 & 12.378 & 0.000 \\
\hline INC3 <- Export Capabilities & $0.789 * * *$ & 0.500 & 0.060 & 13.248 & 0.000 \\
\hline INC4 <- Export Capabilities & $0.714 * * *$ & 0.713 & 0.037 & 19.396 & 0.000 \\
\hline PDC1 <- Export Capabilities & $0.829 * * *$ & 0.829 & 0.024 & 33.834 & 0.000 \\
\hline PDC2 <- Export Capabilities & $0.848 * * *$ & 0.849 & 0.016 & 53.046 & 0.000 \\
\hline PDC3 <- Export Capabilities & $0.865 * * *$ & 0.763 & 0.028 & 30.654 & 0.000 \\
\hline EXR1 <- Export Resource & $0.706 * * *$ & 0.602 & 0.051 & 13.958 & 0.000 \\
\hline EXR2 <- Export Resource & $0.715 * * *$ & 0.573 & 0.063 & 11.257 & 0.000 \\
\hline EXR3 <- Export Resource & $0.713 * * *$ & 0.608 & 0.037 & 19.319 & 0.000 \\
\hline FIR1 <- Export Resource & $0.746 * * *$ & 0.636 & 0.048 & 15.530 & 0.000 \\
\hline FIR2 <- Export Resource & $0.713 * * *$ & 0.476 & 0.069 & 10.374 & 0.000 \\
\hline SOR1 <- Export Resource & $0.744 * * *$ & 0.640 & 0.049 & 15.222 & 0.000 \\
\hline SOR2 <- Export Resource & $0.710 * * *$ & 0.601 & 0.048 & 14.849 & 0.000 \\
\hline PHR1 <- Export Resource & $0.726 * * *$ & 0.724 & 0.037 & 19.661 & 0.000 \\
\hline PHR2 <- Export Resource & $0.737 * * *$ & 0.737 & 0.029 & 25.328 & 0.000 \\
\hline PHR3 <- Export Resource & $0.767 * * *$ & 0.661 & 0.046 & 16.703 & 0.000 \\
\hline FIPR1 <- Export Performance & $0.800 * * *$ & 0.694 & 0.037 & 21.588 & 0.000 \\
\hline FIPR2 <- Export Performance & $0.828 * * *$ & 0.830 & 0.016 & 50.958 & 0.000 \\
\hline FIPR3 <- Export Performance & $0.845 * * *$ & 0.844 & 0.019 & 45.139 & 0.000 \\
\hline PPST1 <- Export Performance & $0.866 * * *$ & 0.758 & 0.035 & 24.937 & 0.000 \\
\hline PPST2 <- Export Performance & $0.721 * * *$ & 0.588 & 0.055 & 13.139 & 0.000 \\
\hline SRPR1 <- Export Performance & $0.833 * * *$ & 0.730 & 0.031 & 27.142 & 0.000 \\
\hline SRPR2 <- Export Performance & $0.864 * * *$ & 0.761 & 0.025 & 35.268 & 0.000 \\
\hline SRPR3 <- Export Performance & $0.801 * * *$ & 0.695 & 0.038 & 20.856 & 0.000 \\
\hline
\end{tabular}

Note. ${ }^{* * *} \mathrm{P}<0.001$ (SmartPLS 33.3, 5000 bootstrapping samples.

\subsection{Structural Model Results}

Hair et al. (2017) proposed assessing the structural model by looking at the $\mathrm{R}^{2}$, beta $(\beta)$, and matching $\mathrm{t}$-values using a bootstrapping approach with a resample of 5,000. They also suggested that, in addition to these core measures, researchers should reveal the effect sizes (f2). A p-value can tell you whether or not there is an effect, but it can't tell you how big it is, according to Sullivan and Feinn (2012). When reporting and analysing studies, both substantive significance (effect size) and statistical significance (p-value) are relevant results to convey (p. 279).

Table 5. Quality criteria

\begin{tabular}{lll}
\hline & R Square & R Square Adjusted \\
\hline EDRM & 0.321 & 0.318 \\
Exporting Capabilities & 0.428 & 0.424 \\
Export Performance & 0.617 & 0.612 \\
\hline
\end{tabular}


The $\mathrm{R}^{2}$ values for each endogenous variable indicate how much variance is explained by the model (Lages et al., 2009a). The condition $\mathrm{R}^{2}$ conditions were met by all endogenous variables. However, the total model explained 61.7 percent of the variance in export performance, 32.1 percent in exporter-distributor relationship management, and 42.8 percent in exporting competence.

\subsection{Hypothesis Testing}

Table 6 illustrates that fourteen (14) of the twenty-five (25) hypotheses with sub hypothesis were supported, with the bootstrap t-values for eleven routes and their corresponding path coefficients failing to satisfy the recommended cut offs.

Table 6. Hypothesis testing

\begin{tabular}{|c|c|c|c|c|c|c|c|}
\hline Hypothesis & Relationship & $\begin{array}{l}\beta \text { path } \\
\text { coefficient }\end{array}$ & Mean (M) & $\begin{array}{l}\text { Standard Deviation } \\
\text { (STDEV) }\end{array}$ & T- Statistics & P Values & Decision \\
\hline $\mathrm{H} 1$ & $\mathrm{ER}->\mathrm{EC}$ & 0.004 & 0.003 & 0.063 & 0.070 & 0.945 & Not Supported \\
\hline H1a & EXR $->E C$ & 0.034 & 0.036 & 0.053 & 0.642 & 0.521 & Not Supported \\
\hline $\mathrm{H} 1 \mathrm{~b}$ & SOR -> EC & 0.015 & 0.015 & 0.056 & 0.261 & 0.794 & Not Supported \\
\hline $\mathrm{H} 1 \mathrm{c}$ & PHR -> EC & $(0.096)$ & $(0.090)$ & 0.062 & 1.536 & 0.125 & Not Supported \\
\hline H1d & FIR $->$ EC & 0.081 & 0.076 & 0.062 & 1.292 & 0.197 & Not Supported \\
\hline H2 & $E R->E P$ & 0.187 & 0.187 & 0.050 & 3.744 & 0.000 & Supported \\
\hline $\mathrm{H} 2 \mathrm{a}$ & EXR -> EP & 0.188 & 0.190 & 0.061 & 3.101 & 0.002 & Supported \\
\hline $\mathrm{H} 2 \mathrm{~b}$ & SOR -> EP & 0.271 & 0.273 & 0.054 & 5.053 & 0.000 & Supported \\
\hline $\mathrm{H} 2 \mathrm{c}$ & PHR -> EP & 0.020 & 0.024 & 0.068 & 0.302 & 0.763 & Not Supported \\
\hline $\mathrm{H} 2 \mathrm{~d}$ & FIR -> EP & 0.024 & 0.020 & 0.047 & 0.515 & 0.607 & Not Supported \\
\hline $\mathrm{H} 3$ & $E R->E C->E P$ & 0.000 & $(0.000)$ & 0.004 & 0.034 & 0.973 & Not Supported \\
\hline $\mathrm{H} 4$ & ER -> EDRM & 0.566 & 0.569 & 0.055 & 10.283 & 0.000 & Supported \\
\hline $\mathrm{H} 4 \mathrm{a}$ & EXR -> EDRM & 0.009 & 0.009 & 0.067 & 0.131 & 0.896 & Not Supported \\
\hline $\mathrm{H} 4 \mathrm{~b}$ & SOR -> EDRM & 0.289 & 0.290 & 0.062 & 4.696 & 0.000 & Supported \\
\hline $\mathrm{H} 4 \mathrm{c}$ & PHR -> EDRM & 0.300 & 0.300 & 0.074 & 4.060 & 0.000 & Supported \\
\hline $\mathrm{H} 4 \mathrm{~d}$ & FIR -> EDRM & 0.164 & 0.161 & 0.062 & 2.621 & 0.009 & Supported \\
\hline $\mathrm{H} 5$ & EDRM-> EP & 0.392 & 0.386 & 0.064 & 6.141 & 0.000 & Supported \\
\hline $\mathrm{H} 5 \mathrm{a}$ & MRWD -> EP & -0.069 & $-0.072-$ & 0.061 & 1.138 & 0.256 & Not Supported \\
\hline $\mathrm{H} 5 \mathrm{~b}$ & $\mathrm{BBC}->\mathrm{EP}$ & 0.354 & 0.354 & 0.057 & 6.199 & 0.000 & Supported \\
\hline $\mathrm{H} 5 \mathrm{c}$ & SOCO -> EP & 0.271 & 0.273 & 0.054 & 5.053 & 0.000 & Supported \\
\hline H6 & ER -> EDRM -> EP & 0.222 & 0.219 & 0.042 & 5.298 & 0.000 & Supported \\
\hline $\mathrm{H} 7$ & EDRM-> EC & 0.652 & 0.658 & 0.045 & 0.652 & 0.000 & Supported \\
\hline $\mathrm{H} 7 \mathrm{a}$ & MRWD -> EC & 0.586 & 0.585 & 0.057 & 10.202 & 0.000 & Supported \\
\hline $\mathrm{H} 7 \mathrm{~b}$ & $\mathrm{BBC}->\mathrm{EC}$ & -0.003 & 0.000 & 0.059 & 0.046 & 0.964 & Not Supported \\
\hline $\mathrm{H} 7 \mathrm{c}$ & SOCO $->$ EC & 0.259 & 0.257 & 0.050 & 5.203 & 0.000 & Supported \\
\hline Control Variable & $\mathrm{CV}->\mathrm{EP}$ & 0.342 & 0.350 & 0.053 & 6.500 & 0.000 & Supported \\
\hline
\end{tabular}

Note. ER: 'Export Resource’, EC: 'Export Capabilities’, EDRM: 'Export-Distributor’ Relationship Management', EP: ‘Export Performance’, CV: 'Control Variable', EXR; Experiential Resources, SOR: Scale of Operation Resources, PHR: Physical Resources; FIR: Financial Resources, MRWD: Out Come based Control; BBC: Behaviour-Based (Process) Control; SOCO: Social Control; CV: Control Variable 


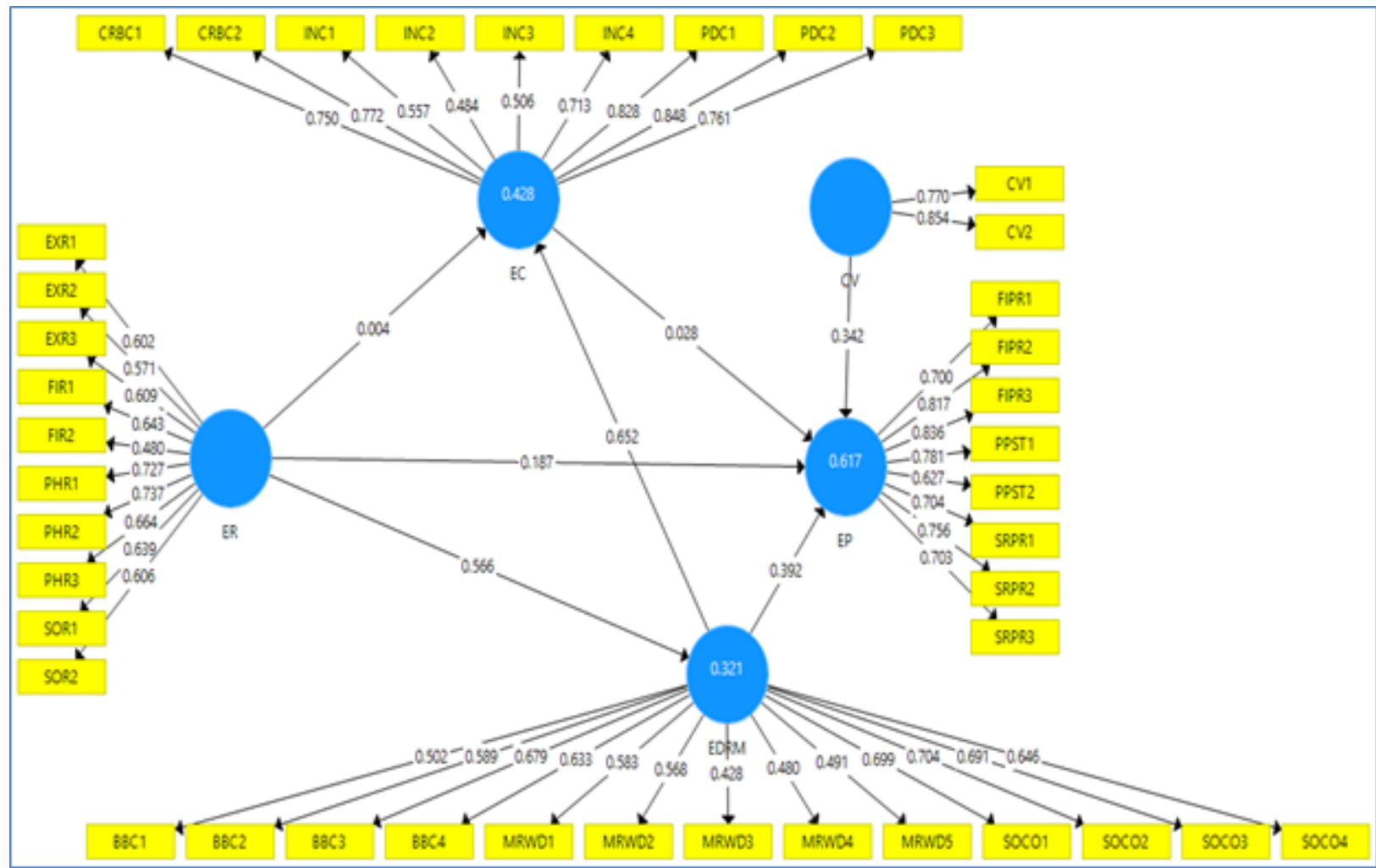

Figure 2. Exploring the relationship between export resources, export capabilities \& controlling and managing foreign distributers with export performance model with SEM results

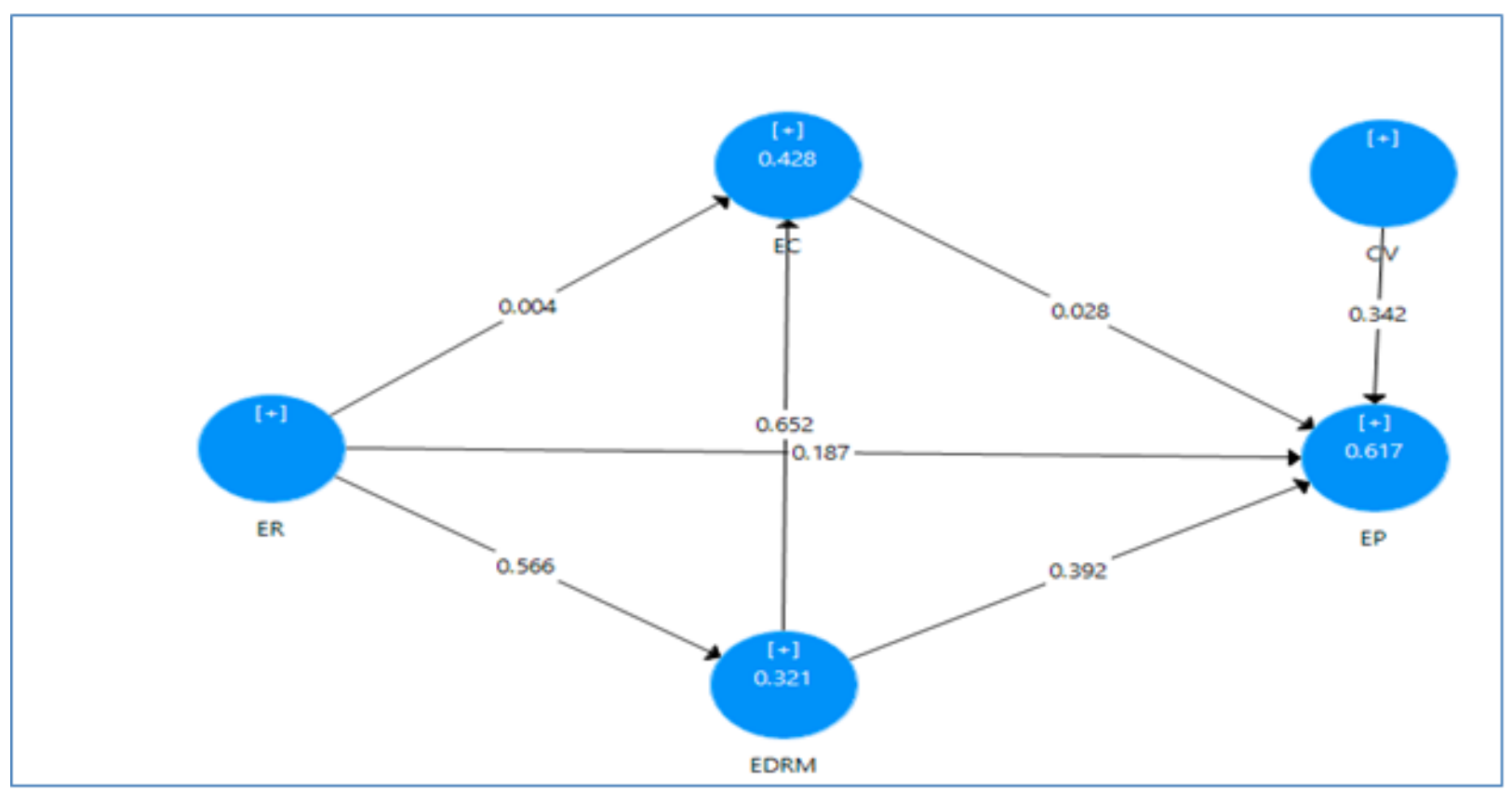

Figure 3. Exploring the relationship between export resources, export capabilities exporter-foreign distributers and export performance results

\section{Discussion of the Hypothesis of the Study}

H1: There is a significant and positive relationship between Export Resources and Export Capabilities

Export performance had no significant impact on export resources and capabilities $(\beta=0.004, \mathrm{P}=0.945>0.05)$. 
As a result, H-1 is rejected. Fung et al. (2007), on the other hand, believe that a lack of corporate resources for analyzing and applying export market knowledge will lead to exporting companies making decisions based on gut instinct rather than informed strategic decision-making. Despite this, researchers disagree about the relationship between export resources and export capabilities. As a result, having resources alone might not be enough to establish export capacity.

\section{H-2: There is a significant and positive relationship between Export Resources and Export Performance.}

Export Resources has a significant and positive effect on Export Performance $(\beta=0.187 ; \mathrm{P}=.000<0.05)$. As a result, H-3 has been accepted. As a result, H-3 was accepted. This finding is in line with Kaleka's (2012) findings, which identify four types of competitive resources for exporters: physical assets, size of operation, financial assets, and experience in export market operations (2011). According to Kaleka (2012), the bulk of these critical resources have a favorable impact on a variety of outcomes in an inter-organizational setting.

\section{H-3: Export Capabilities Mediate the Relationship between Export Resources and Export Performance}

Export capabilities did not mediate the relationship between export resources and export performance $(\beta=0.000, P$ $=0.973>0.05)$. As a result, $\mathbf{H - 3}$ was rejected. The results of this study contradict those of previous studies. Learning and knowledge (Hung, 2010), institutional capital and managerial relationships (Lu et al., 2010), and social networks, for example, all serve as mediators between resources and performance (Pinho et al., 2016). The ability of a company to utilize and restructure resources over time in order to produce new types of long-term competitive advantage is referred to as dynamic capabilities (Pinho et al., 2016; Tan et al., 2015). Only a few competitors can match a company's assets, knowledge, and talents to gain a cost or differentiation advantage.

H-4: There is a significant and positive relationship between Export Resources and Exporter -Distributor Relationship.

Export Resources had a significant impact on the Exporter-Distributor Relationship $(\beta=0.566, \mathrm{P}=0.000<0.05)$. As a result, H-4 was approved. This result is in line with prior studies. According to Spyropoulou et al. (2018), these Resource talents combine to achieve strategic goals in export markets in exporter-foreign intermediary partnerships. Exporting firms manage intermediaries to create conditions that enable them to achieve targeted outcomes and contribute to the creation and implementation of the intermediary's strategic goals in order to generate value for their businesses (Sachdev et al., 1994; De Mortanges et al., 1999).

\section{H-5: There is a significant and positive relationship between Exporter-distributer relationship and Export} Performance.

The exporter-distributor relationship has a significant impact on export performance $(\beta=0.392, \mathrm{P}=0.000<0.05)$. As a result, H-5 has been accepted. The findings of this study stand up Knight's (2000) claim that export intermediaries have a significant impact on export performance. Intermediaries have a huge impact on SME export success, according to Trabold (2002) and Peng et al. (2001). It also agrees with Peng and Ilinitch (1998), who argue that export intermediates are specialized service businesses that connect local manufacturers and overseas clients by adding value to the export process and are essential to SME export success by giving value to the export process. Wilkinson and Nguyen (2003) also argue that strong exporter-intermediary relationships and coordination are required for successful export sales.

H-6: Exporter-Distributer relationships mediate the relationship between Export Resources and Export Capabilities.

The relationship between Export Resources and Export Performance was mediated by proper management of the Exporter-Distributor Relationship $(\beta=0.222, \mathrm{P}=0.000<0.05)$. As a result, H-6 was approved. This study's findings are consistent with previous studies. According to Lu et al. (2010), the firm's ability to coordinate, recombine, and allocate resources to meet multiple demands mediates the resource-performance Relationship.

H-7: There is a Significant and Positive Relationship between Exporter-distributer Relationship Management and Export Capabilities.

The exporter and distributor's relationship had a significant and positive impact on export capability $(\beta=0.652, \mathrm{P}$ $=0.000<0.05$ ). As a result, $\mathbf{H}-7$ was accepted. This discovery is in line with prior research findings. According to $\mathrm{Ma}$ (2006), the ability to develop positive relationships between exporters and export intermediaries is a potentially important intermediate resource base and export capability. According to Donaldson (1998), personal connection with the market and strong ties with channel members improve the exporter's capacity to plan and manage sales in export markets. It also agrees with Shipley et al. (1998), who claim that establishing informal relationships is the best way to manage and regulate Distributors. Strong bonds based on communication, 
cooperation, and trust

\section{Control Variable}

Control variables were used to resolve validity problems. The company's exports Importance is a proxy variable for export intensity, which is defined as the ratio of export sales to total sales revenue (Westhead et al., 2001). The second control variable used in this study is the importance of the export relationship, as measured by the percentage of sales from this relationship with the foreign intermediary. This variable indicates the total exposure to potential opportunism and the requirements for coordination with the intermediary (Dekker et al., 2013).

\section{Conclusion}

Export performance and economic growth relationships are becoming increasingly important in international and regional development initiatives. The purpose of this research was to look into the relationship between export resources, exporting capability, and the relationships between exporters and overseas distributors, as well as their impact on export performance. The Ethiopian Chamber of Commerce and sectoral organizations submitted a list of exporters as the sampling frame. The companies were chosen at random from a pool of 300 exporting companies that met the following criteria: they were independent entities with a strong international focus, they earned a significant amount of money from export operations, they had at least five years of experience in the export business, and they had contact information for senior managers and experts.

To analyze the data, PLS-SEM (Partial Least Squares Structural Equation Modeling) was employed. Data validity and reliability were also assessed using a two-stage analytical technique. The impact of export capability and exporter-distributor relationship management on the relationship between export resources and export performance was investigated in this study. Exporter-Distributor Relationship Management mediated the linkage between export resources and export performance. Export capacity, on the other hand, was unable to mediate the relationship between export resources and export performance. Exporters are advised to maintain and promote exporter-intermediary relationships in order to boost export performance (MacKinnon et al., 2004).

\section{Study Limitations and Direction for Further Research}

A number of issues limit the conclusions and implications, emphasizing that more research is needed in this area. To begin, this study encompassed all exporters, including small, medium, and large export companies. Future research could examine at the distinctions between larger, medium, and small exporters in the export business, as each has varied resources, qualified staff, bargaining strength, and so on. Second, this study focused solely on the viewpoints of exporters, with no regard for the viewpoints of overseas distributors. As a result, other academics can conduct research from the perspective of international distributors. Third, the current analysis found that, contrary to earlier research, export capabilities failed to mediate the relationship between export resources and export performance. More research, such as focus groups or in-depth interviews with exporters, is required to have a greater understanding of the complexities. Fourth, subjective measures were used in this study due to the difficulty in acquiring aggregated export performance reports. Finally, the study suggests that as ties between exporters and foreign intermediaries grow so will exporters' ability to earn money.

\section{Reference}

Acedo, F. J., \& Casillas, J. C. (2007). Age at entry in international markets of Spanish SMEs: Entrepreneurial and institutional determinants. International Journal of Entrepreneurship Behaviour Research, 13, 130-150. https://doi.org/10.1108/13552550710751021

Allaro H. (2012). The effect of export-led growth strategy on the Ethiopian economy. American Journal of Economics, 2(3), 50-56. https://doi.org/10.5923/j.economics.20120203.05

Amit, R., \& Schoemaker, P. (1993). Strategic assets and organizational rent. Strategy. Management Journal, 14, 33-46. https://doi.org/10.1002/smj.4250140105

Andaleeb, S., \& Anwar, S. (1996). Factors influencing customer trust in salespersons in a developing country. Journal of International Marketing, 4(4), 35-52. https://doi.org/10.1177/1069031X9600400404

Anderson, J. C., \& Gerbing, D. W. (1988). Structural equation modeling in practice: A review and recommended two-step approach. Psychological Bulletin, 103(3), 411-423. https://doi.org/10.1037/0033-2909.103.3.411

Armstrong, C. E., \& Shimizu, K. (2007). A Review of Approaches to Empirical Research on the Resource-Based View of the Firm. Journal of Management, 33, 959-986. https://doi.org/10.1177/0149206307307645

Aulakh, P. S., \& Gencturk, E. F. (2000). International principal-agent relationships. Control, governance and $\begin{array}{llll}\text { performance. } & \text { Industrial }\end{array}$ 
https://doi.org/10.1016/S0019-8501(00)00126-7

Barney, J. B. (1991). Firm resources and sustained competitive advantage. Journal of Management, 17, 99-120. https://doi.org/10.1177/014920639101700108

Barney, J. B. (2001). Is the Resource-Based "View" a Useful Perspective for Strategic Management Research? Yes. Academy of Management Review, 26, 41-56. https://doi.org/10.5465/amr.2001.4011938

Barney, J. B., Wright, M., \& Ketchen, D. J. (2001). The resource-based view of the firm: Ten years after 1991. Journal of Management, 27, 625-641. https://doi.org/10.1177/014920630102700601

Beamish, P., Karavis, L., Goerzen, A., \& Lane, C. (1999). The relationship between organization structure and export performance. Management International Review, 39(1), 37-54.

Bello, D. C., Chelariu, C., \& Zhang, L. (2003). The antecedents and performance consequences of relationalism export distribution channels. Journal of Business Research, 56, 1-16. https://doi.org/10.1016/S0148-2963(01)00215-6

Bello, D. C., \& Gilliland, D. I. (1997). The effect of output controls, process controls and flexibility on export channel performance. Journal of Marketing, 61, 22-38. https://doi.org/10.1177/002224299706100103

Bloemer, J., Pluymaekers, M., \& Odekerken, A. (2013). Trust and affective commitment as energizing forces for export performance. International Business Review, 22(2), 363-380. https://doi.org/10.1016/j.ibusrev.2012.05.002

Boso, N., Story, V. M., Cadogan, J. W., Micevski, M., \& Kadić-Maglajlić, S. (2013). Firm innovativeness and export performance: Environmental, networking, and structural contingencies. Journal of Marketing Research, 21(4), 62-87. https://doi.org/10.1509/jim.13.0052

Cavusgil, S. T., \& Zou, S. (1994). Marketing strategy-performance relationship: An investigation of the empirical link in export market ventures. Journal of Marketing, 58, 1-21. https://doi.org/10.1177/002224299405800101

Cavusgil, Y., \& Mitri. (1995). Selecting foreign distributer: An expert systems approach. Industrial Marketing Management, 24, 297-304. https://doi.org/10.1016/0019-8501(95)00013-Z

Chen, D., Paik, Y., \& Park, S. H. (2010). Host-country policies and MNE management control in IJVs: Evidence from China. Journal of International Business Studies, 41, 526-537. https://doi.org/10.1057/jibs.2009.97

Chen, X., Zou, H., \& Wang, D. T. (2009). How do new ventures grow? Firm capabilities, growth strategies and performance. International Journal of Research in Marketing, 26(4), 294-303. https://doi.org/10.1016/j.jiresmar.2009.08.004

Chin, W. (1998a). Issues and opinions on structural equation modeling. MIS Quarterly, 22(1), 7-16.

Chin, W. W. (1998b). The partial least squares approach to structural equation modeling. In G. A. Marcoulides (Ed.), Modern Methods for Business Research (pp. 295-358). Erlbaum, Mahwah, NJ.

Cohen, J. (1988). Statistical power analysis for the behavioral sciences. Mahwah, NJ: Lawrence Erlbaum.

Collis, D. J. (1994). Research Note: How Valuable Are Organizational Capabilities? Strategic Management Journal, 15(winter: Special Issue), 143-152. https://doi.org/10.1016/j.ijresmar.2009.08.004

Connor, T. (2002). The Resource-Based View of Strategy and Its Value to Practicing Managers. Strategic Change, 11, 307-316. https://doi.org/10.1002/jsc.593

Das, T. K., \& Teng, B. S. (1988). Between trust and control: Developing confidence in partner cooperation in alliances. Academic Management Review, 23, 491-512. https://doi.org/10.2307/259291

Das, T. K., \& Teng, B. S. (2004). The Risk-Based View of trust: A conceptual framework. J. Bus. Psychol., 19, 85-116. https://doi.org/10.1023/B:JOBU.0000040274.23551.1b

De Mortanges, C. P., \& Vossen, J. (1999). Mechanisms to control the marketing activities of foreign distributors. Int. Bus. Rev., 8, 75-97. https://doi.org/10.1016/S0969-5931(98)00039-0

Dekker, H. C., Sakaguchi, J., \& Kawai, T. (2013). Beyond the contract: Managing risk in supply chain relations. Management Accounting Research, 24, 122-139. https://doi.org/10.1016/j.mar.2013.04.010

Dhanaraj, C., \& Beamish, P. W. (2003). A resource-based approach to the study of export performance. Journal of Small Business Management, 41, 242-261. https://doi.org/10.1111/1540-627X.00080

Doaei, K., \& Hosseini, S. (2011). Analysing the impact of customer perception of the value of bran. 
Donaldson, B. (1998). Sales Management: Theory and Practice (2nd ed.). Basing Stoke, Macmillan.

Dyer, J. H. (1997). Effective inter-firm collaboration: How firms minimise transaction costs and maximise transaction value. Strategic Management Journal, 18(7), 535-556. https://doi.org/10.1002/(SICI)1097-0266(199708)18:7<535::AID-SMJ885>3.0.CO;2-Z

Fiol, C. M. (2001). Revisiting an Identity-Based View of Sustainable Competitive Advantage. Journal of Management, 27, 691-699. https://doi.org/10.1177/014920630102700606

Fornell, C., \& Larcker, D. F. (1981). Evaluating structural equation models with unobservable variables and measurement error. Journal of Marketing Research, 18, 39-50. https://doi.org/10.1177/002224378101800104

Foss, N. J. (1996a). Knowledge-Based Approaches to the Theory of the Firm: Some Critical Comments. Organization Science, 7, 470-476. https://doi.org/10.1287/orsc.7.5.470

Foss, N. J. (1996b). More Critical Comments on Knowledge-Based Theories of the Firm. Organization Science, 7, 519-523. https://doi.org/10.1287/orsc.7.5.519

Gefen, D., \& Straub, D. (2005). A practical guide to factorial validity using PL-Graph: Tutorial and annotated example. Communications of the Association for Information Systems, 16, 91-109. https://doi.org/10.17705/1CAIS.01605

Gholami, R., Sulaiman, A. B., Ramayah, T., \& Molla, A. (2013). Senior managers' perception on green information systems (IS) adoption and environmental performance: Results from a field survey. Information and Management, 50(7), 431-438. https://doi.org/10.1016/j.im.2013.01.004

Gibbert, M. (2006a). Generalizing About Uniqueness: An Essay on an Apparent Paradox in the Resource-Based View. Journal of Management Inquiry, 15, 124-134. https://doi.org/10.1177/1056492606287793

Gibbert, M. (2006b). Munchausen, Black Swans, and the RBV: Response to Levitas and Ndofor. Journal of Management Inquiry, 15, 145-151. https://doi.org/10.1177/1056492606287797

Gudergan, S. P., Ringle, C. M., Wende, S., \& Will, A. (2008). Confirmatory tetrad analysis in PLS path modeling. Journal of Business Research, 61(12), 1238-1249. https://doi.org/10.1016/j.jbusres.2008.01.012

Guenzi, P., Baldauf, A., \& Panagopoulos, N. G. (2014). The influence of formal and informal sales controls on customer-directed selling behaviors and sales unit effectiveness. Industrial Marketing Management, 43, 786-800. https://doi.org/10.1016/j.indmarman.2014.04.014

Haas, R. W. (1995). Business Marketing: A managerial Approach (6th ed.). Cincinnati Ohio, south western college.

Hahn, E. D., \& Ang, S. H. (2017). From the editors: New directions in the reporting of statistical results in the Journal of World Business. Journal of World Business, 52, 125-126. https://doi.org/10.1016/j.jwb.2016.12.003

Hair, J. F., Hult, G. T. M., Ringle, C. M., \& Sarstedt, M. (2017). A Primer on Partial Least Squares Structural Equation Modeling (2nd ed.). Thousand Oaks: Sage. https://doi.org/10.15358/9783800653614

Helfat, C. E., \& Peteraf, M. A (2003). The dynamic resource-based view: Capability lifecycles. Strategy Management Journal, 14, 997-1010. https://doi.org/10.1002/smj.332

HenselerJörg, J. H. (2016). Guest editorial. Industrial Management \& Data Systems, 116(9), 1842-1848. https://doi.org/10.1108/IMDS-09-2016-0366

Hill, S. M., \& Blois, K. J. (1989). Industrial Distributers and small manufacturers. European Journal of Marketing, 23(2), 154-152. https://doi.org/10.1108/EUM0000000000554

Hsu, L.-C., \& Wang, C.-H. (2012). clarifying the effect of intellectual capital on performance: The mediating role of dynamic capability. Br. J. Manag., 23, 179-205. https://doi.org/10.1111/j.1467-8551.2010.00718.x

Hulland, J. (1999). Use of Partial Least Squares (PLS) in Strategic Management Research: A review of four recent studies. Strategic Management Journal, 20, 195-204. https://doi.org/10.1002/(SICI)1097-0266(199902)20:2<195::AID-SMJ13>3.0.CO;2-7

Hung, R. Y. Y., Yang, B., Lien, B. Y.-H., McLean, G. N., \& Kuo, Y.-M. (2010). Dynamic capability: Impact of process alignment and organizational learning culture on performance. J. World Bus., 45, 258-294. https://doi.org/10.1016/j.jwb.2009.09.003 
Inkpen, A., \& Currall, S. C. (2004). The coevolution of trust, control, and learning in Joint Ventures. Organ. Sci., 15, 586-599. https://doi.org/10.1287/orsc.1040.0079

International Labour Office. (2015). Global Economic Inequality and International Trade. Switzerland: ILO Publications.

Jaworski, B. J. (1988). Toward a theory of marketing control: Environmental context, control types, and consequences. Journal of Marketing, 52, 23-39. https://doi.org/10.1177/002224298805200303

Kaleka, A. (2002). Resources and capabilities driving competitive advantage in export markets: Guidelines for industrial exporters. Industrial Marketing Management, 31, 273-283. https://doi.org/10.1016/S0019-8501(00)00148-6

Kaleka, A. (2011). When exporting manufacturers compete on the basis of service: Resources and marketing capabilities driving service advantage and performance. Journal of International Marketing, 19, 40-58. https://doi.org/10.1509/jimk.19.1.40

Kaleka, A. (2012). Studying resource and capability effects on export venture performance. Journal of World Business, 47, 93-105. https://doi.org/10.1016/j.jwb.2010.10.024

Kang, J., Asare, A. K., Brashear-Alejandro, T., Granot, E., \& Li, P. (2018) Interorganizational drivers of channel performance: A meta-analytic structural model. Journal of Business and Industrial Marketing, 33, 183-195. https://doi.org/10.1108/JBIM-09-2016-0218

Karami, M., \& Tang, J. (2019). Entrepreneurial orientation and SME international performance: The mediating role of networking capability and experiential learning. International Small Business Journal, 37(2), 105-124. https://doi.org/10.1177/0266242618807275

Katsikeas, C. S., Leonidou, L. C., \& Morgan, N. A. (2000). Firm-level export performance assessment: Review, evaluation and development. Journal of Academic Marketing Science, 28, 493-511. https://doi.org/10.1177/0092070300284003

Kim, W. G., Han, J. S., \& Lee, E. (2001). Effects of relationship marketing on repeat purchase and word of mouth. Journal of Hospitality \& Tourism Research, 25(3), 272-288. https://doi.org/10.1177/109634800102500303

Knight, G. (2000). Entrepreneurship and marketing strategy: The SME under globalization. Journal of International Marketing, 8(2), 12-32. https://doi.org/10.1509/jimk.8.2.12.19620

Kock, N., \& Verville, J. (2012). Exploring free questionnaire data with anchor variables: An illustration based on a study of IT in healthcare. International Journal of Healthcare Information Systems and Informatics, 7(1), 46-63. https://doi.org/10.4018/jhisi.2012010104

Kogut, B. (1988). Joint ventures: Theoretical and empirical perspectives. Strategic Management Journal, 9(4), 319-332. https://doi.org/10.1002/smj.4250090403

Kogut, B., \& Zander, U. (1992). Knowledge of the Firm, Combinative Capabilities, and the Replication of Technology. Organization Science, 3, 383-397. https://doi.org/10.1287/orsc.3.3.383

Lakew, B. (2003). Prospects for export diversification in Ethiopia. NBE Staff Working Paper $\mathrm{ERD} / \mathrm{SWP} / 007 / 2003$.

Leonidou, L. C., Katsikeas, C. S., \& Samiee, S. (2002). Marketing strategy determinants of export performance: A meta-analysis. Journal of Business Research, 55, 51-67. https://doi.org/10.1016/S0148-2963(00)00133-8

Lewin, J. W., \& Johnston, W. J. (1997). International Sales force management: A relationship Perspective. Journal of Business and Industrial Marketing, 12(3), 2360. https://doi.org/10.1108/08858629710188063

Lin, K. H., \& Chaney, I. (2007). The influence of domestic interfirm networks on the internationalization process of Taiwanese SMEs. Asia Pacific Business Review, 13(4), 565-583. https://doi.org/10.1080/13602380701345499

Lu, V. N., Quester, P. G., Medlin, C. J., \& Scholz, B. (2012). Determinants of export success in professional business services: A qualitative study. The Service Industries Journal, 32(10), 1637-1652. https://doi.org/10.1080/02642069.2012.665893

Lu, Y., Zhou, L., Bruton, G., \& Li, W. (2010). Capabilities as a mediator linking resources and the international Performance of entrepreneurial firms in an emerging economy. Journal of International Business Studies, 41, 419-436. https://doi.org/10.1057/jibs.2009.73 
Ma, X. (2006). Beyond transaction cost determinants: An integrated framework for export intermediary selection in emerging economies. Advances in International Marketing, 16, 23-48. https://doi.org/10.1016/S1474-7979(05)16002-5

MacKinnon, D., Chapman, K., \& Cumbers, A. (2004). Networking, trust and embeddedness amongst SMEs in the Aberdeen oil complex. Entrep. Reg. Dev., 16, 87-106. https://doi.org/10.1080/08985620410001677826

Madsen, T. K., \& Moen, Ø. (2018). Managerial assessments of export performance: What do they reflect? International Business Review, 27(2), 380-388. https://doi.org/10.1016/j.ibusrev.2017.09.005

Mellewigt, T., Ehrmann, T., \& Decker, C. (2011). How does the franchisor's choice of different control mechanisms affect franchisees' and employee-managers' satisfaction? Journal of Retail., 87, 320-331. https://doi.org/10.1016/j.jretai.2011.01.001

Miller, D. (2003). An Asymmetry-Based View of Advantage: Towards an Attainable Sustainability. Strategic Management Journal, 24, 961-976. https://doi.org/10.1002/smj.316

Musteen, M., Datta, D. K., \& Butts, M. M. (2014). Do international networks and foreign market knowledge facilitate SME internationalization? Evidence from the Czech Republic. Entrepreneurship Theory and Practice, 38(4), 749-774. https://doi.org/10.1111/etap.12025

Newbert, S. L. (2007). Empirical Research on the Resource-Based View of the Firm: An Assessment and Suggestions for Future Research. Strategic Management Journal, 28, 121-146. https://doi.org/10.1002/smj.573

Ouchi, W. G. (1979). A conceptual framework for the design of organizational control mechanisms. Management Science, 25, 833-848. https://doi.org/10.1287/mnsc.25.9.833

Peng, M. W., \& Ilinitch, A. Y. (1998). Export intermediary firms: a note on export development research. Journal of International Business Studies, 29(3), 609-620. https://doi.org/10.1057/palgrave.jibs.8490010

Peng, M. W., \& York, S. A. (2001). Behind intermediary performance in export trade: Transactions, agent, and resources. Journal of International Business Studies, 32(2), 327-346. https://doi.org/10.1057/palgrave.jibs.8490955

Pinho, J. C., \& Prange, C. (2016). The effect of social networks and dynamic internationalization capabilities on international performance. Journal of World Business, 51, 391-403. https://doi.org/10.1016/j.jwb.2015.08.001

Priem, R. L., \& Butler, J. E. (2001a). Is the Resource-Based "View" a Useful Perspective for Strategic Management Research? Academy of Management Review, 26, 22-40. https://doi.org/10.5465/amr.2001.4011928

Rahman, S. A., Amran, A., Ahmad, N. H., \& Taghizadeh, S. K. (2015). Supporting entrepreneurial business success at the base of pyramid through entrepreneurial competencies. Management Decision, 53(6), 1203-1223. https://doi.org/10.1108/MD-08-2014-0531

Rahman, S. A., Amran, A., Ahmad, N. H., \& Taghizadeh, S. K. (2016). Enhancing the wellbeing of base of the pyramid entrepreneurs through business success: The role of private organizations. Social Indicators Research, 127(1), 195-216. https://doi.org/10.1007/s11205-015-0951-4

Ramayah, T., Lee, J. W. C., \& Boey, J. C. I. (2011). Network collaboration and performance in the tourism sector. Service Business, 5(4), 411-428. https://doi.org/10.1007/s11628-011-0120-z

Ramayah, T., Yeap, J. A. L., \& Ignatius, J. (2013). An empirical inquiry on knowledge sharing among academicians in higher learning institutions. Minerva: A Review of Science. Learning and Policy, 51(2), 131-154. https://doi.org/10.1007/s11024-013-9229-7

Ramsey, R., \& Sohi, R. (1997). Listening to your customers: the impact of perceived salesperson listening behavior on relationship outcomes. Journal of the Academy of Marketing Science, 25, 127-137. https://doi.org/10.1007/BF02894348

Redding, S. G. (1996). Asian Business Networks - Google Books. DE GRUYTER STUDIES IN....

Ripollés, M., Blesa, A., \& Monferrer, D. (2012). Factors enhancing the choice of higher resource commitment entry modes in international new ventures. International Business Review, 21(4), 648-666. https://doi.org/10.1016/j.ibusrev.2011.07.007

Robson, M. J., Leonidou, L. C., \& Katsikeas, C. S. (2002). Factors influencing international joint venture 
performance: Theoretical perspectives, assessment, and future directions. Management International Review, 42(4), 385-418.

Root, F. R. (1994). Entry strategies for international markets. Newyork, Lexington Books.

Sachdev, H. J., Bello, D. C., \& Pilling, B. K. (1994). Control mechanisms within export channels of distribution. J. Glob. Mark., 8, 31-49. https://doi.org/10.1300/J042v08n02_03

Shamdasani, P., \& Balakrishnan, A. (2000). Determinants of relationship quality and loyalty in personalized services. Asia Pacific Journal of Management, 17, 399-422. https://doi.org/10.1023/A:1015834214570

Shipley, D., Cook, D., \& Barnett, E. (1989). Recruitment, Motivation, Training and Evaluation of Overseas Distributers. European Journal of Marketing, 23(2), 79-93. https://doi.org/10.1108/EUM0000000000548

Shoham, A. (1991). Performance in exporting: A state of the art literature review and synthesis and directions for future research. In Proceedings of the Conference of the Academy of International Business, Miami, FL, USA, 17-21 October 1991.

Shoham, A. (1998). Export performance: A conceptualization and empirical assessment. Journal of International Marketing, 6, 59-81. https://doi.org/10.1177/1069031X9800600308

Spyropoulou, S., Katsikeas, C. S., Skarmeas, D., \& Morgan, N. A. (2018). Strategic goal accomplishment in export ventures: The role of capabilities, knowledge, and environment. J. Acad. Mark. Sci., 46, 109-129. https://doi.org/10.1007/s11747-017-0519-8

Stoian, M.-C., Rialp, A., \& Rialp, J. (2011). Export performance under the microscope: A glance through Spanish lenses. Int. Bus. Rev., 20, 117-135. https://doi.org/10.1016/j.ibusrev.2010.07.002

Su, S., Baird, K., \& Schoch, H. (2013). Management control systems from an organizational life cycle perspective: The role of input, behaviour and output controls. Journal of Management Organization, 19, 635-658. https://doi.org/10.1017/jmo.2014.7

Sullivan, G. M., \& Feinn, R. (2012). Using Effect Size - or why the p Value is not enough. Journal of Graduate Medical Education, 4(3), 279-282. https://doi.org/10.4300/JGME-D-12-00156.1

Tan, Q., \& Sousa, C. M. P. (2015). Leveraging marketing capabilities into competitive advantage and export performance. International Marketing Review, 32, 78-102. https://doi.org/10.1108/IMR-12-2013-0279

Teece, D. J., Pisano, G., \& Shuen, A. (1997) Dynamic capabilities and strategic management. Strategy. Management Journal, 18,

18, 509-533. https://doi.org/10.1002/(SICI)1097-0266(199708)18:7<509::AID-SMJ882>3.0.CO;2-Z

Trabold, H. (2002). Export intermediation: an empirical test of Peng and Ilinitch. Journal of International Business Studies, 33(2), 327-344. https://doi.org/10.1057/palgrave.jibs.8491019

Weerawardena, J., Mort, G. S., \& Liesch, P. W. (2019). Capabilities development and deployment activities in born global B-to-B firms for early entry into international markets. Industrial Marketing Management, 78, 122-136. https://doi.org/10.1016/j.indmarman.2017.06.004

Wernerfelt, B. (1984). A resource-based view of the firm. Strategic Management Journal, 5(2), 171-180. https://doi.org/10.1002/smj.4250050207

Werts, C. E., Linn, R. L., \& Karl, G. J. (1974). Intraclass reliability estimates: Testing structural assumptions. Educational and Psychological Measurement, 34(1), 25-33. https://doi.org/10.1177/001316447403400104

Westhead, P., Wright, M., \& Ucbasaran, D. (2001). The internationalization of new and small firms: A Resource-Based view. Journal of Business Ventur, 16, 333-358. https://doi.org/10.1016/S0883-9026(99)00063-4

Wilkinson, I. F., \& Nguyen, V. (2003). A contingency model of export entry mode performance: The role of production and transactions costs. Australasian Marketing Journal, 11(3), 44-60. https://doi.org/10.1016/S1441-3582(03)70134-7

Williamson, O. E., \& Winter, S. G. (Eds.). (1991). The Nature of the Firm: Origins, Evolution, and Development. New York: Oxford University Press.

Zajac, E. J., \& Olsen, C. P. (1993). From transaction cost to transactional value analysis: Implications for the study of interorganizational strategies. Journal of Management Studies, 30(1), 131-145. https://doi.org/10.1111/j.1467-6486.1993.tb00298.x 
Zou, S., Taylor, C. R., \& Osland, G. E. (1998). The EXPERF scale: A cross-national generalized export performance measure. Journal of International Marketing, 6, 37-58. https://doi.org/10.1177/1069031X9800600307

\section{Copyrights}

Copyright for this article is retained by the author, with first publication rights granted to the journal.

This is an open-access article distributed under the terms and conditions of the Creative Commons Attribution license (http://creativecommons.org/licenses/by/4.0/). 